\title{
Soluble Neuregulin-1 Has Bifunctional, Concentration-Dependent Effects on Schwann Cell Myelination
}

\author{
Neeraja Syed, ${ }^{1 \star}$ Kavya Reddy, ${ }^{1 \star}$ David P. Yang, ${ }^{1}$ Carla Taveggia, ${ }^{2}$ James L. Salzer, ${ }^{3}$ Patrice Maurel, ${ }^{1}$ and Haesun A. Kim ${ }^{1}$ \\ ${ }^{1}$ Department of Biological Sciences, Rutgers University, Newark, New Jersey 07102, ${ }^{2}$ Instituto di Neurologia Sperimentale, San Raffaele Scientific Institute, \\ 20132 Milan, Italy, and ${ }^{3}$ Smilow Neuroscience Program, Department of Cell Biology and Neurology, New York University School of Medicine, \\ New York, New York 10016
}

\begin{abstract}
Members of the neuregulin-1 (Nrg1) growth factor family play important roles during Schwann cell development. Recently, it has been shown that the membrane-bound type III isoform is required for Schwann cell myelination. Interestingly, however, Nrg1 type II, a soluble isoform, inhibits the process. The mechanisms underlying these isoform-specific effects are unknown. It is possible that myelination requires juxtacrine Nrg1 signaling provided by the membrane-bound isoform, whereas paracrine stimulation by soluble Nrg1 inhibits the process. To investigate this, we asked whether Nrg1 type III provided in a paracrine manner would promote or inhibit myelination. We found that soluble Nrg1 type III enhanced myelination in Schwann cell-neuron cocultures. It improved myelination of Nrg1 type III ${ }^{+/-}$ neurons and induced myelination on normally nonmyelinated sympathetic neurons. However, soluble Nrg1 type III failed to induce myelination on Nrg1 type III ${ }^{-/-}$neurons. To our surprise, low concentrations of Nrg1 type II also elicited a similar promyelinating effect. At high doses, however, both type II and III isoforms inhibited myelination and increased c-Jun expression in a manner dependent on Mek/Erk (mitogen-activated protein kinase kinase/extracellular signal-regulated kinase) activation. These results indicate that paracrine Nrg1 signaling provides concentration-dependent bifunctional effects on Schwann cell myelination. Furthermore, our studies suggest that there may be two distinct steps in Schwann cell myelination: an initial phase dependent on juxtacrine Nrg1 signaling and a later phase that can be promoted by paracrine stimulation.
\end{abstract}

\section{Introduction}

Schwann cell development in the peripheral nervous system (PNS) is dependent on contact-mediated signaling between Schwann cells and the associated axons. The neuregulin-1 (Nrg1) and erbB ligand-receptor system lends itself to the task of close contact signaling, as PNS neurons express Nrg1 family ligands and Schwann cells express erbB2 and erbB3, which heterodimerize to form functional Nrg1 receptors (Falls, 2003).

Members of the Nrg1 family of growth factor are initially expressed on the PNS axons as transmembrane proteins, which are then shed from the membrane by proteolytic processing. All isoforms, types I, II, and III, contain an epidermal growth factor (EGF)-like signaling domain in the extracellular domain that is necessary and sufficient for activating erbB receptors on the Schwann cell surface (Holmes et al., 1992; Lu et al., 1995). They differ, however, in the sequences N-terminal to the EGF domain; the type I and II isoforms contain an Ig-like domain, whereas type III isoform contains a cysteine-rich domain, which functions as a

\footnotetext{
Received April 7, 2009; revised March 5, 2010; accepted March 23, 2010.

This work was supported by grants from the National Institute of Health (NS056135 to H.A.K. and NS26001 to J.L.S.), the New Jersey Commission on Spinal Cord Research (to H.A.K.), and the New Jersey Commission on Brain Injury Research (to H.A.K.). C.T. is a recipient of a transition career award (2007/PC/01) from FISM-Federazione Italiana Sclerosi Multipla.

${ }^{*} N . S$. and K.R. contributed equally to this work.

Correspondence should be addressed to Haesun A. Kim, Rutgers University, Department of Biological Sciences, Boyden Hall, Room 206, 195 University Avenue, Newark, NJ 07102. E-mail: haekim@andromeda.rutgers.edu. DOI:10.1523/JNEUROSCI.1681-09.2010

Copyright $\odot 2010$ the authors $\quad 0270-6474 / 10 / 306122-10 \$ 15.00 / 0$
}

second transmembrane domain. As a result, Nrg1 type I and II are released and function as paracrine signals after proteolytic cleavage, whereas Nrg1 type III remains tethered to the axonal membrane and mediates juxtacrine signaling (Falls, 2003).

Recent studies have shown that membrane-bound Nrg1 type III plays an essential role in initiating and regulating myelination in the PNS. Axons that lack Nrg1 type III expression fail to become myelinated (Taveggia et al., 2005). Overexpression of Nrg1 type III in neurons results in hypermyelination, indicating that the levels of myelination are determined by the amount of Nrg1 type III expressed on individual axons (Michailov et al., 2004; Taveggia et al., 2005). In contrast, soluble Nrg1 type II has been shown to inhibit Schwann cell myelination and promote dedifferentiation (Zanazzi et al., 2001). Since both Nrg1 isoforms bind and activate erbB receptors, it is unclear how they elicit opposing effects on myelination. It is possible that juxtacrine signaling provided by the membrane-bound $\mathrm{Nrg} 1$ is required for myelination, whereas paracrine signaling by soluble isoforms prevents the process. Alternatively, the isoform-specific effects may be mediated by differential activation of the erbB receptor downstream signaling pathways.

To address the issue, we investigated the effect of Nrg1 type III, presented in a paracrine manner, on Schwann cell myelination. We report that soluble Nrgl type III elicits a promyelinating function in Schwann cell-neuron cocultures. It increases myelination of Nrg1 type III ${ }^{+/-}$neurons but fails to myelinate Nrg1 type III $^{-1-}$ neurons. Interestingly, low concentrations of Nrg1 type II also promote myelination, suggesting that the effect is not 
isoform-specific. At high concentrations, both Nrg1 isoforms inhibit myelination in a manner dependent on Mek/Erk (mitogenactivated protein kinase kinase/extracellular signal-regulated kinase) activation. Altogether, our data suggest that the promyelinating function of Nrg1 is not limited to the juxtacrine signal and can be provided by a paracrine signal in a concentrationdependent manner. Finally, our studies suggest that there may be two distinct steps of Schwann cell myelination: an initial phase dependent on membrane-bound Nrg1 signaling, and a later phase that can be promoted by soluble Nrg1 isoforms.

\section{Materials and Methods}

Antibodies. For immunofluorescence analysis, monoclonal antibody (SMI94) to myelin basic protein (MBP) (Covance) was used at 1:300 dilution. For Western blot analysis, monoclonal antibody to phosphoAkt (p-Akt) (Cell Signaling Technology) and polyclonal antibody to phospho-Erk1/2 (Promega) were used at 1:1000 and 1:5000, respectively. Polyclonal antibodies to Akt (Cell Signaling Technology) and Erk1/2 (Promega) were used at 1:1000 and 1:5000, respectively. Polyclonal antibodies to erbB, phospho-erbB2, erbB3, and phospho-erbB3 were used at 1:500 (Santa Cruz Biotechnology). Polyclonal antibody to Krox 20 (Covance) was used at 1:500, polyclonal antibody to MBP (Millipore Bioscience Research Reagents) was used at 1:3000, polyclonal chicken antibody to P0 (Millipore Bioscience Research Reagents) was used at 1:1000, polyclonal antibody to c-Jun (Santa Cruz Biotechnology) was used at 1:400, and monoclonal antibody to $\alpha$-actin (Sigma-Aldrich) was used at 1:5000 dilution.

Type II, type III, and EGF domain neuregulin-1. Recombinant human sensory and motor neuron-derived factor (rhSMDF, type III Nrg1) was purchased from R\&D Systems. Recombinant human glial growth factor-II (rhGGF-II, type II Nrg1) was obtained from Acorda Therapeutics under a material transfer agreement. In this study, rhSMDF and rhGGF-II are referred simply as soluble Nrg1 type III and GGF, respectively. The soluble Nrg1 type III was the peptide with N-terminal 296 amino acid residues containing both the EGF domain and cysteine-rich domain (CRD) (Ho et al., 1995). The GGF was the peptide with $\mathrm{N}$-terminal 519 amino acid residues containing the EGF domain and the Ig-like domain (Marchionni et al., 1993). Both Nrg1 peptides lacked the transmembrane and cytoplasmic domains. The recombinant human EGF domain fragment of Nrg1 (EGF-Nrg1) was obtained from R\&D Systems.

Primary rat Schwann cell culture. Schwann cells were prepared from sciatic nerves of newborn rats (1-2 d old) as described previously (Brockes et al., 1979). For routine culture, Schwann cells were grown in DMEM (Mediatech) with 10\% fetal bovine serum (FBS) (Mediatech) supplemented with $10 \mathrm{ng} / \mathrm{ml}$ EGF-Nrg1 and $5 \mu \mathrm{M}$ forskolin (SigmaAldrich). Cells between passages 2 and 4 were used in all experiments described in the text.

In vitro myelination: dorsal root ganglion neuron-Schwann cell cocultures. Dissociated dorsal root ganglion (DRG) was prepared from embryonic day (E) 15.5 rat embryos or E13.5 mouse embryos as described previously (Eldridge et al., 1987) and plated onto type-1 rat tail collagencoated $12 \mathrm{~mm}$ glass coverslips at a density of $1.25 \mathrm{DRG} /$ coverslip. Five to six hours later, the cultures were flooded with neurobasal medium (Mediatech) supplemented with B27 (Invitrogen), 0.08\% glucose, NGF (50 $\mathrm{ng} / \mathrm{ml}$ ), and a mixture of $15 \mu \mathrm{M} 5$-fluorodeoxyuridine (FdUr) (SigmaAldrich) and uridine (Sigma-Aldrich). Cultures were maintained in the medium for additional 2-3 d to remove proliferating non-neuronal cells and then switched to fresh medium without FdUr and uridine mixture and maintained until the DRG axons reached the periphery of the coverslips. After the axonal networks were established, Schwann cells were plated onto the neurons at a density of 150,000 cells/coverslip in Minimal Essential Medium (MEM) (Mediatech) supplemented with 10\% FBS, $0.08 \%$ glucose, and $50 \mathrm{ng} / \mathrm{ml} \mathrm{NGF}$. Five to seven days later, cultures were switched to myelinating medium: MEM supplemented with 10\% FBS, $0.08 \%$ glucose, NGF $(50 \mathrm{ng} / \mathrm{ml})$, and ascorbic acid $(50 \mu \mathrm{g} / \mathrm{ml})$. Eleven days later, myelination was assessed by immunostaining for MBP. Solu- ble Nrg1 or U0126 was added at the time of switching to the myelinating medium and replenished every $2 \mathrm{~d}$.

Schwann cell proliferation in cocultures. Bromodeoxyuridine (BrdU; 10 $\mu \mathrm{M})$ was added to the cocultures at the time of the Nrg1 treatment. Sixteen hours later, cultures were fixed in cold methanol and immunostained for BrdU. Briefly, fixed cultures were treated with $2 \mathrm{~N} \mathrm{HCl}$ for 15 min at $37^{\circ} \mathrm{C}$. Cells were washed 3 times in $0.1 \mathrm{~m}$ borate buffer $(\mathrm{pH} 8.5)$ over a 10 min period and then washed 3 times in PBS in the same manner. Cultures were incubated in blocking solution (5\% normal goat serum supplemented with $0.2 \%$ Triton X-100) for 30 min and incubated with monoclonal BrdU antibody prepared in blocking solution for $1 \mathrm{~h}$ at room temperature. Cy2-conjugated goat anti-mouse secondary antibody was added for $1 \mathrm{~h}$ and, before mounting, cells were incubated with $4^{\prime} 6$ diamidino-2-phenylindole $2 \mathrm{HCl}$ (DAPI) for $1 \mathrm{~min}$ to visualize nuclei. Percentage of BrdU-incorporated Schwann cells was determined by counting the number of BrdU-positive nuclei among the DAPI-positive nuclei of the axon-associated Schwann cells.

In vitro myelination: superior cervical ganglion neuron-Schwann cell cocultures. Dissociated superior cervical ganglion (SCG) neurons were prepared from postnatal day 1-2 rats as described previously (Johnson, 2001) and plated onto collagen-coated $12 \mathrm{~mm}$ glass coverslips at a density of $0.8 \mathrm{SCG} /$ coverslip. Next day, the cultures were flooded with neurobasal medium supplemented with B27, 0.08\% glucose, NGF (50 ng/ml), and a mixture of FdUr and uridine $(10 \mu \mathrm{M})$ and maintained in the medium for an additional 2-3 d to remove proliferating non-neuronal cells. The cultures were switched back to fresh medium without FdUr and uridine mixture and maintained until the axons extended out to the periphery of the coverslips. Schwann cells were plated onto the neurons at a density of 200,000 cells/coverslip and maintained in MEM supplemented with $10 \%$ FBS, $0.08 \%$ glucose, and $50 \mathrm{ng} / \mathrm{ml} \mathrm{NGF}$ until the Schwann cells populated the axons $(\sim 7-10 \mathrm{~d})$. Myelination was initiated by placing the cultures in myelinating medium as described for DRGSchwann cell coculture. Five to six weeks later, myelination was assessed by MBP immunostaining. Soluble Nrg1 was added at the time the cultures were placed in myelinating medium and replenished every $2 \mathrm{~d}$.

Immunofluorescence staining for MBP. DRG-Schwann cell or SCGSchwann cell cocultures were rinsed in PBS and then fixed in $4 \%$ paraformaldehyde for $20 \mathrm{~min}$. After washing with PBS, samples were permeabilized in ice-cold methanol for $25 \mathrm{~min}$ and then incubated in blocking solution ( $5 \%$ normal goat-serum plus $0.3 \%$ Triton X-100) for $1 \mathrm{~h}$ at room temperature. This was followed by incubation with MBP primary antibody prepared in blocking solution overnight. After washing with PBS, samples were incubated with Alexa 488-conjugated goat antimouse secondary antibody (Invitrogen) for $45 \mathrm{~min}$. Cell nuclei were stained with DAPI. After mounting, $\mathrm{MBP}^{+}$myelin segments were examined by epifluorescence on a Nikon E800 microscope.

Assessment of myelination (myelin index). Myelin index was determined as an average fold increase in the number of myelin segments formed in experimental cultures compared with the control cultures. To account for the variability in myelin formation in individual cultures, we established three or four individual coverslips for each experimental condition, and myelin segments, visualized by MBP immunostaining, were counted on all coverslips. For control cultures, pairwise comparisons were made between all coverslips within the group, yielding 9 or 16 ratios per experiment. Ratios from multiple, independent experiments were then averaged and the value was expressed as the myelin index \pm SEM for control. A value close to 1 indicates minimal variation in myelination within the control group. For the myelin index in an experimental group, a similar strategy was used to make pairwise comparisons between three or four experimental coverslips and the control coverslips within an experiment. The experimental to control ratios from multiple experiments were then averaged, yielding the myelin index \pm SEM for each experimental group.

Measurement of myelin segment length. Following immunostaining for $\mathrm{MBP}, \mathrm{MBP}^{+}$myelin segments from 5 to 10 random fields per coverslip were photographed using a $40 \times$ objective lens. The digitized images were analyzed using MetaMorph software (MDS Analytical Technology) for measuring lengths of individual myelin segments. A total of 200-700 individual segments were analyzed from three separate experiments. 
A
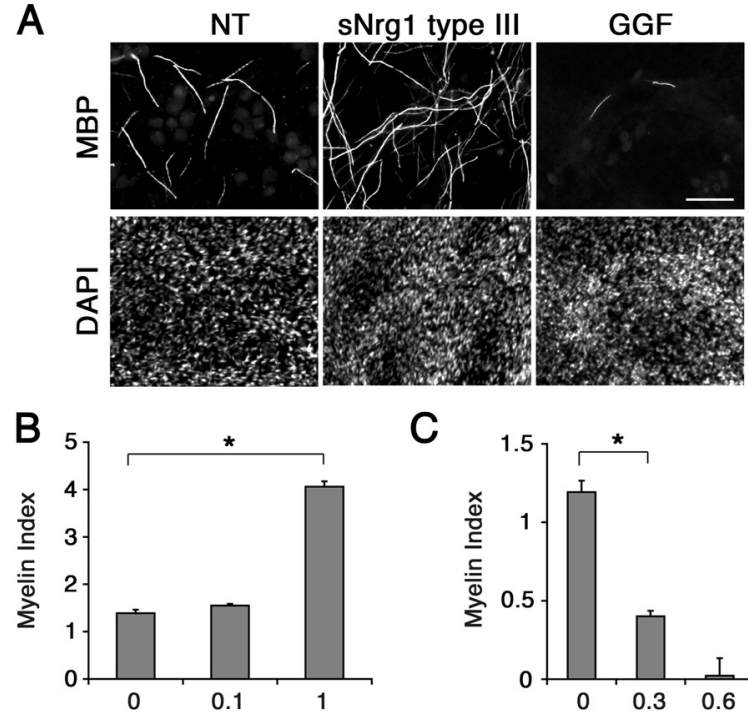

C

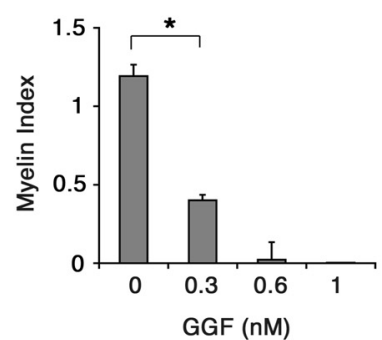

sNrg1 type III (nM)

D
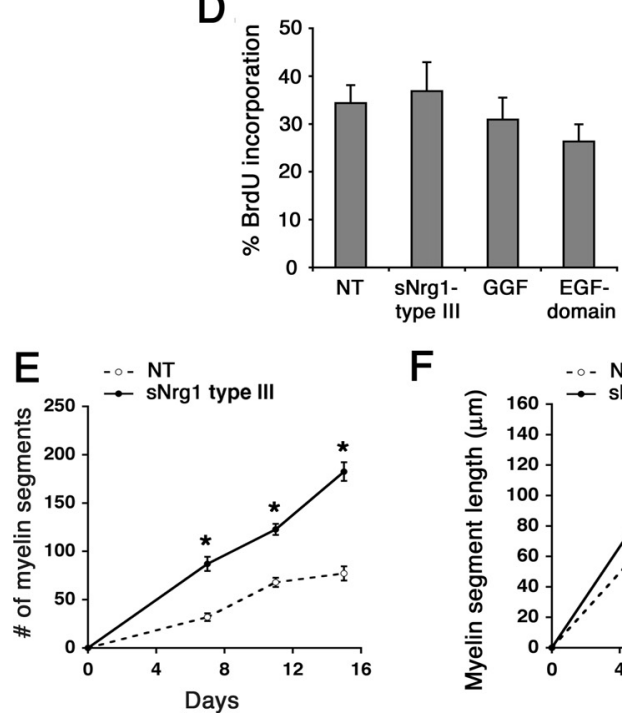

$\mathbf{F}$

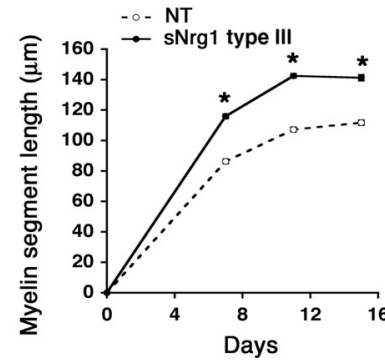

Figure 1. Soluble Nrg1 type III promotes Schwann cell myelination. A, Images of myelin segments formed in cocultures treated with soluble Nrg1 type III or GGF at $1 \mathrm{~nm}$. Nrg1 was added at the time of initiating myelination and remained for $11 \mathrm{~d}$, at which time the cultures were fixed and immunostained for MBP and DAPI. Scale bar, $100 \mu \mathrm{m}$. B, Quantification of myelination in cultures treated with soluble Nrg1 type III at 0.1 and $1 \mathrm{~nm}$. C, Myelination in the presence of GGF $(0.3,0.6$, and $1 \mathrm{~nm})$. For $\boldsymbol{B}$ and $\boldsymbol{C}$, the data were collected from $10-12$ coverslips/condition from three separate experiments. $\boldsymbol{D}$, Schwann cell proliferation in cocultures. Two hundred thousand Schwann cells were seeded onto dissociated DRG neurons. Three days later, the cocultures were treated with $\mathrm{Nrg} 1$ as indicated. Sixteen to eighteen hours later, BrdU was added and $24 \mathrm{~h}$ later the cultures were processed for BrdU immunostaining. There was no significant change in Schwann cell proliferation in cultures treated with soluble Nrg1 type III, GGF or EGF-Nrg1 ( $p=0.427$ ). The means \pm SEM were determined from five coverslips/condition from two separate experiments. $\boldsymbol{E}$, Upon initiation of myelination (day 0 ), cocultures were treated with or without soluble $\mathrm{Nrg} 1$ type III (1 nM), and the number of total myelin segments was counted on days 7,11 , and 15 . There was a significant increase $\left({ }^{*} p<0.001\right)$ in the number of myelin segments in sNrg1 type III-treated cultures compared with the nontreated (NT) control. $\boldsymbol{F}$, The lengths of individual myelin segments were measured from myelinating cocultures, maintained with or without (NT) sNrg1 type III (1 nM) for $11 \mathrm{~d}$. There was also a significant increase $\left(^{*} p<0.001\right)$ in the myelin segment length (mean \pm SEM, $n=200$ ) in cultures treated with soluble Nrg1 type III at all time points.

Statistical analysis. One-way ANOVA followed by post hoc analysis was performed for all experiments using SigmaStat 3.5 software.

Western blot analysis. To prepare cell lysates, cocultures were washed twice in PBS and then lysed in $300 \mu \mathrm{l}$ of ice-cold lysis buffer $(20 \mathrm{~mm}$
A

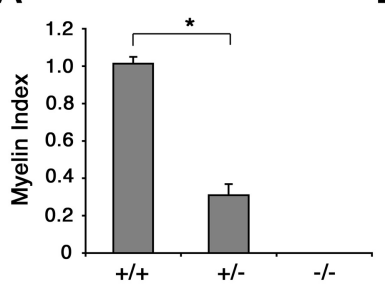

B $\square$ Wild type $\square \mathrm{Nrg} 1$ type $\mathrm{III}^{+/-}$

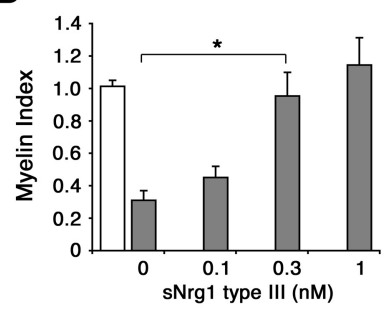

C

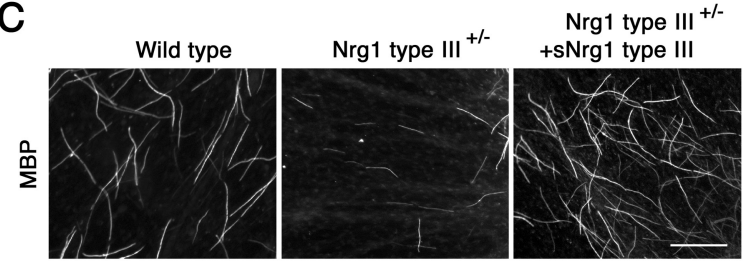

D

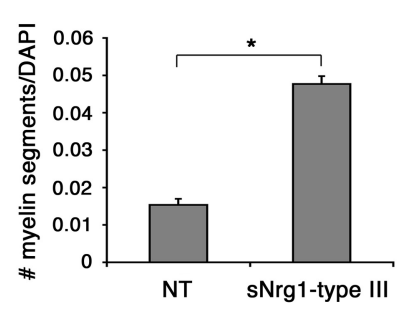

E

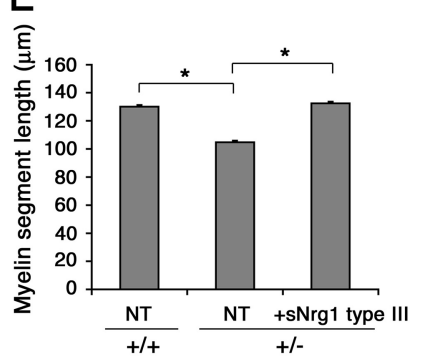

F

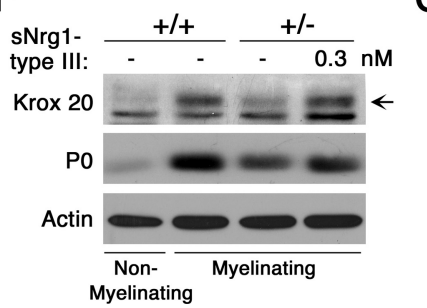

G

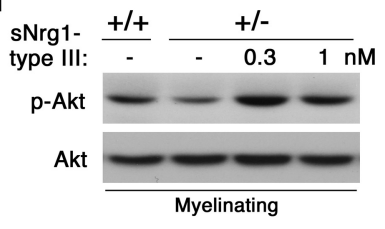

Figure 2. Soluble Nrg1 type III rescues the myelination defect on Nrg1 type $\mathrm{III}^{+/-}$ neurons. A, DRG neurons from wild-type $(+/+)$, Nrg1 type III ${ }^{+/-}(+/-)$, and $\mathrm{Nrg} 1$ type III ${ }^{-I-}(-/-)$ mouse embryos were cocultured with rat Schwann cells and maintained in myelinating media for $11 \mathrm{~d}$. Quantification of the number of myelin segments showed a significant decrease $\left({ }^{*} p<0.001\right)$ in myelination in Nrg1 type III ${ }^{+/-}$cultures, whereas no myelination was observed on $\mathrm{Nrg} 1$ type $\mathrm{II}^{-1-}$ neurons. B, Myelination in Nrg1 type $\mathrm{III}^{+/-}$cocultures (gray bars) treated with soluble Nrg1 type III. Wild-type cultures were used as control (white bar). In $\boldsymbol{A}$ and $\boldsymbol{B}$, data show the means \pm SEM for each condition from three independent experiments. $C$, Images of myelin segments formed in wild-type and Nrg1 type III ${ }^{+/-}$cultures treated with soluble Nrg1 type III (1 nM). Scale bar, $100 \mu \mathrm{m}$. D. The number of myelin segments per DAPI-positive Schwann cell nucleus in 11 day myelinating $\mathrm{Nrg} 1$ type $\mathrm{III}^{+/-}$cocultures. A significant increase $\left({ }^{*} p<0.001\right)$ in myelination is seen cultures treated with soluble Nrg1 type III. The means ( \pm SEM) from three independent experiments are shown. $\boldsymbol{E}$, The mean ( \pm SEM) individual myelin segment lengths in wild-type $(+/+)$ and $\mathrm{Nrg} 1$ type III heterozygous $(+/-)$ cocultures on day 11 after initiating myelination. Treatment with soluble Nrg1 type III increased the myelin segment length in $\mathrm{Nrg} 1$ type $\mathrm{III}^{+/-}$cultures to the wild-type level $(n=700$, $\left.{ }^{*} p<0.001\right)$. $\boldsymbol{F}$, Soluble Nrg1 type III increases Krox 20 expression in Nrg1 type $\mathrm{III}^{+/-}$ cocultures. Lysates were prepared from $\mathrm{Nrg} 1$ type $\mathrm{III}^{+/-}$cocultures maintained in the presence of soluble $\mathrm{Nrg} 1$ type III ( $0.3 \mathrm{~nm})$ for $11 \mathrm{~d}$ under myelinating conditions, and Krox 20 and $\mathrm{P} 0$ expression was determined by immunoblotting. Wild-type cultures under nonmyelinating and myelinating conditions served as negative and positive controls. G, Soluble Nrg1 type III increases Akt activation in Nrg1 type $\mathrm{III}^{+/-}$cocultures. Wild-type $(+/+)$ or $\mathrm{Nrg} 1$ type $\mathrm{III}^{+/-}(+/-)$cocultures under myelinating conditions were treated with soluble $\mathrm{Nrg} 1$ type III as indicated. Forty-five minutes later, cell lysates were prepared and p-Akt levels were detected by immunoblotting. NT, Nontreated. 
A

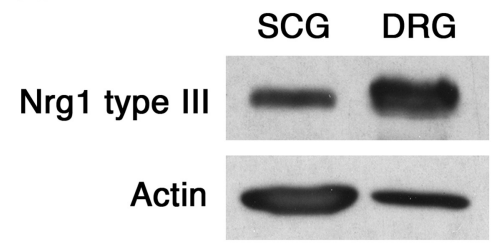

B

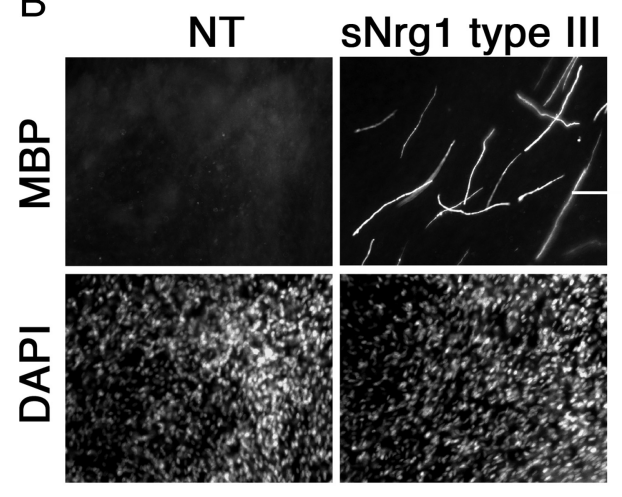

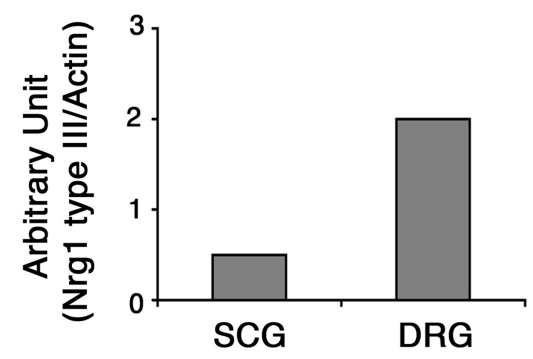

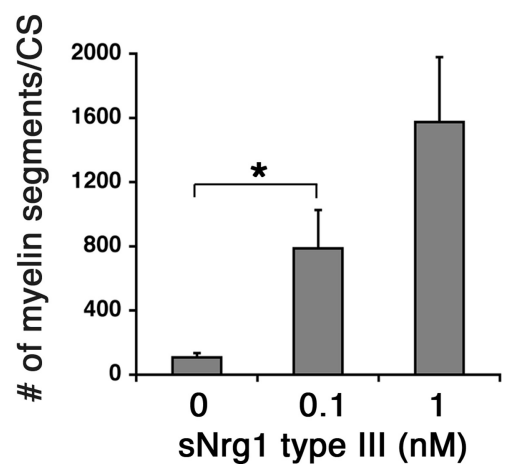

Figure 3. Soluble Nrg1 type III induces myelination on normally nonmyelinated SCG neurons. $\boldsymbol{A}$, Expression levels of Nrg1 type III in SCG and DRG neurons. Cell lysates were prepared from purified SCG and DRG neurons grown on coverslips, and the Nrg1 type III levels were determined by immunoblotting. Quantification is shown on the right, in which the levels of Nrg1 type III are normalized against the levels of actin. $\boldsymbol{B}$, Schwann cell-SCG cocultures were maintained in myelinating media in the absence [nontreated (NT)] or presence of soluble Nrg1 type III (1 nM) for 6 weeks. Cultures were fixed and immunostained for MBP and DAPI. Scale bar: $100 \mu \mathrm{m}$. Quantification of the result is shown on the right. Treatment with Nrg1 type III (1 nm) induced myelination on SCG neurons in a dose-dependent manner ( ${ }^{*} p<0.002$ ). The means \pm SEM from 12 coverslips/condition from four independent experiments are shown.

Tris- $\mathrm{HCl}$, pH 7.4, 1\% Nonidet P-40, 10\% glycerol, 2.5 mm EGTA, 2.5 mm EDTA, $150 \mathrm{~mm} \mathrm{NaCl}, 20 \mu \mathrm{M}$ leupeptin, $10 \mu \mathrm{g} / \mathrm{ml}$ aprotinin, $1 \mathrm{~mm}$ phenylmethylsulfonyl fluoride (PMSF), and $1 \mathrm{~mm}$ sodium orthovanadate). Lysates were cleared by centrifugation for $15 \mathrm{~min}$ at $14,000 \mathrm{rpm}$ in the cold, and the protein concentration of the supernatants was determined. Twenty micrograms of the lysates were size fractionated on 10\% SDSpolyacrylamide gel and transferred onto polyvinylidene difluoride membrane. After blocking in 5\% milk, the membranes were incubated with appropriate primary antibodies prepared in 5\% BSA in TBST (TBS plus $0.05 \%$ Tween 20 ). After incubation with HRP-conjugated secondary antibodies, the protein bands were visualized by enhanced chemiluminescence (ECL).

\section{Results}

Soluble Nrg1 type III enhances Schwann cell myelination

To assess the role of soluble Nrg1 type III during myelination, we used a well established in vitro myelinating culture system in which Schwann cells were cocultured with DRG neurons and induced to myelinate by adding ascorbic acid to the culture medium (Eldridge et al., 1987). As a source of soluble Nrg1 type III, we used the extracellular N-terminal 296 amino acid residues containing the EGF domain and the CRD (Ho et al., 1995). This recombinant $\mathrm{Nrg} 1$ protein has been shown to activate erbB receptors and the downstream signaling pathways in Schwann cells (Taveggia et al., 2005). Primary rat Schwann cells were seeded onto DRG neurons and allowed to proliferate in association with the axons. At the time of initiating myelination (day 0), cultures were treated and continuously maintained in the presence of the $\mathrm{Nrg} 1(0.1$ or $1 \mathrm{nM})$. Eleven days later, cultures were fixed and immunostained for MBP to visualize myelin segments. Representative images of the cultures are shown in Figure $1 \mathrm{~A}$. Cultures treated with 1 nм soluble $\mathrm{Nrg} 1$ type III ( $\mathrm{N} \mathrm{Nrg} 1$ type III) appeared to have a substantial increase in the number of myelin segments compared with nontreated (NT) control cultures. Quantification of the result is shown in Figure $1 B$; cultures treated with $1 \mathrm{~nm} \mathrm{Nrg} 1$ had a 2.9-fold increase in the number of myelin segments over control. In contrast, soluble $\mathrm{Nrg} 1$ type II (GGF) (Marchionni et al., 1993) inhibited myelination on DRG neurons in a dose-dependent manner (Fig. $1 A, C$ ) as shown previously (Zanazzi et al., 2001). The recombinant EGF domain of Nrg1 (EGF-Nrg1) had an effect similar to that of GGF, resulting in a 2.3-fold decrease and an almost complete inhibition of myelination when used at 0.3 and $0.6 \mathrm{~nm}$, respectively (myelin index: NT, $1.28 \pm \mathrm{SE}$ 0.31; 0.3 nM EGF domain, $0.56 \pm$ SE 0.09; $0.6 \mathrm{nM}$ EGF domain, $0.005 \pm$ SE 0.003 ). None of the Nrg1 isoforms had a significant effect on Schwann cell proliferation in cocultures (Fig. 1D).

To further analyze the myelinationpromoting effect of soluble Nrg1 type III, we compared the numbers and lengths of myelin segments formed over time during the course of myelination in control and Nrg1-treated cultures. In control cultures, the number of myelin segments increased steadily following the addition of ascorbic acid (day 0 ) as expected (Fig. $1 E$ ). In cultures treated with $\mathrm{Nrg} 1$ type III, the number increased more rapidly, resulting in a 2.1-, 1.8-, and 2.3-fold increase over the control on days 7, 11 and 15, respectively. There was also a significant increase in the myelin segment length: 86 , 107 , and $112 \mu \mathrm{m}$ in control cultures versus 116, 142, and $141 \mu \mathrm{m}$ in Nrg1 type III-treated cultures on the corresponding days (Fig. $1 F)$. Together, these results suggest that soluble Nrg1 type III elicits a promyelinating function in Schwann cells.

\section{Soluble Nrg1 type III rescues the myelination defect on Nrg1 type III-deficient neurons}

Mice deficient in Nrg1 type III expression exhibit defects in Schwann cell myelination. In heterozygous mutant mice, neurons are thinly myelinated and Schwann cells express reduced levels of myelin proteins and promyelinating transcription factors (Michailov et al., 2004; Taveggia et al., 2005). When DRG neurons from wild-type, $\mathrm{Nrg} 1$ type $\mathrm{III}^{+/-}$, and $\mathrm{Nrg} 1$ type $\mathrm{III}^{-/-}$ neurons were cocultured with Schwann cells under myelinating conditions, there was a marked decrease in the level of myelination in Nrg1 type $\mathrm{III}^{+/-}$compared with wild-type cultures (Fig. $2 A$ ), confirming the previous in vivo findings (Michailov et al., 2004; Taveggia et al., 2005). Neurons from Nrg1 type $\mathrm{III}^{-/-}$mice failed to myelinate as reported previously (Taveggia et al., 2005). To determine whether soluble Nrg1 type III could rescue the myelination defects in these neurons, wild-type or mutant cocultures were treated with increasing concentrations of Nrg1 type III $(0.1,0.3$, and $1 \mathrm{nM})$, and myelination was assessed as described above. We found that soluble $\mathrm{Nrg} 1$ at 0.3 and $1 \mathrm{~nm}$ restored myelination in Nrg1 type $\mathrm{III}^{+/-}$cultures to wild-type levels (Fig. $2 B)$. Representative images are shown in Figure $2 C$. A similar 
result was obtained when the number of myelin segments was normalized against the number of Schwann cells, indicating that the improved myelination was not due to an increase in Schwann cell number following Nrg1 treatment (Fig. 2D). In addition, there was no obvious cell death in both control and Nrg1-treated cultures (data not shown). Neuregulin also increased the myelin segment length in Nrg1 type III ${ }^{+/-}$cultures to the wildtype level (Fig. 2E). Soluble Nrg1, however, failed to induce myelination on Nrg1

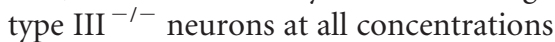
tested (data not shown), in agreement with an earlier report (Taveggia et al., 2005). Therefore, ectopic stimulation with soluble Nrg1 type III rescues myelination defects on Nrg1 type III $^{+/-}$, but not Nrg1 type III ${ }^{-/-}$, neurons.

The promyelinating function of soluble Nrg1 type III is accompanied by an increase in Krox-20 and phosphoinositide 3-kinase activation Schwann cells in Nrg1 type $\mathrm{III}^{+/-}$mice express low levels of promyelinating transcription factors Krox 20 and Oct 6 (Taveggia et al., 2005). To determine whether the myelination rescue by soluble Nrg1 type III was accompanied by an increase in the transcription factor expression, we assessed the levels of Krox 20 as well P0, a myelin-related protein, in cocultures treated with the Nrg1. Wild-type cocultures, under nonmyelinating [minus $(-)$ ascorbic acid] and myelinating conditions [plus $(+)$ ascorbic acid], served respectively as negative and positive controls. Under myelinating conditions, P0 and Krox20 expression levels increased in wild-type cultures, whereas the levels remained low in Nrg1 type III $^{+/-}$cultures. In the presence of soluble Nrg1 type III, the expression levels increased in Nrg1 type III $^{+/-}$cultures (Fig. 2 F).

Membrane-bound Nrg1 type III on the axonal surface is the key Nrg1 isoform that activates the phosphoinositide 3-kinase (PI3-kinase) pathway in associated Schwann cells (Taveggia et al., 2005). Since activation of PI3-kinase and the effector Akt is crucial for initiating myelination (Maurel and Salzer, 2000; Ogata et al., 2004), we asked whether Akt activation is decreased in Nrg1

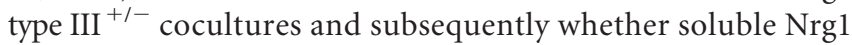
type III could increase the activation level. As shown in Figure $2 G$, under myelinating conditions, the level of active Akt (p-Akt) was substantially decreased in Nrg1 type $\mathrm{III}^{+/-}$cocultures compared with the wild type. Treatment with soluble Nrg1 type III subsequently increased the p-Akt level. These results indicate that the promyelinating function of soluble Nrg1 type III is associated with an increase in Krox-20 and activation of the key signaling pathway required for myelination.

Soluble Nrg1 type III is sufficient to induce myelination on normally nonmyelinated sympathetic neurons

Small diameter axons, such as those of sympathetic neurons, do not become myelinated but ensheathed due to the low levels of Nrg1 type III expression; forced expression of the type III isoform into these neurons converts them into myelinated ones, highlighting the instructive role of the axonal Nrg1 in determining the myelination state of the PNS neurons (Taveggia et al., 2005). Therefore, we asked whether soluble Nrg1 type III was sufficient to induce myelination on normally nonmyelinated axons. Sympathetic neurons of the SCG were prepared from postnatal day 2 rats and cocultured with Schwann cells. These neurons expressed lower levels of Nrg1 type III compared with the neurons of DRG (Fig. 3A), as shown previously (Taveggia et al., 2005). Once the Schwann cells expanded along the axons, the cultures were maintained under myelinating conditions in the continuous presence of soluble Nrg1 type III ( 0.1 or $1 \mathrm{nM})$ for 6 weeks and then fixed and immunostained for MBP. Images and quantification of the cultures are shown in Figure $3 B$. In control cultures, only a handful of myelin segments were formed despite the lengthy myelination period, which is expected of the low-myelination property of Schwann cells associated with sympathetic neurons. On the contrary, a significant number of myelin segments were formed in cultures treated with the soluble Nrg1. This result indicates that the promyelinating function of soluble Nrg1 is sufficient to induce myelination on normally nonmyelinated small diameter axons.

\section{Inhibition of Mek1/Erk activation blocks the inhibitory} function of GGF on myelination

The myelin-promoting effect of soluble Nrg1 type III contrasts with the inhibitory effect of GGF and the EGF-Nrg1 on myelina- 
A

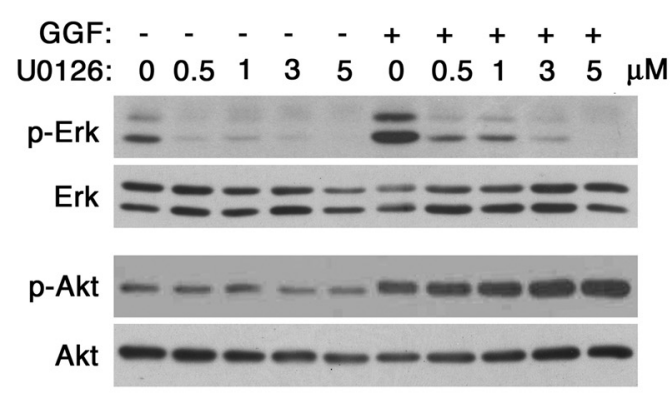

B
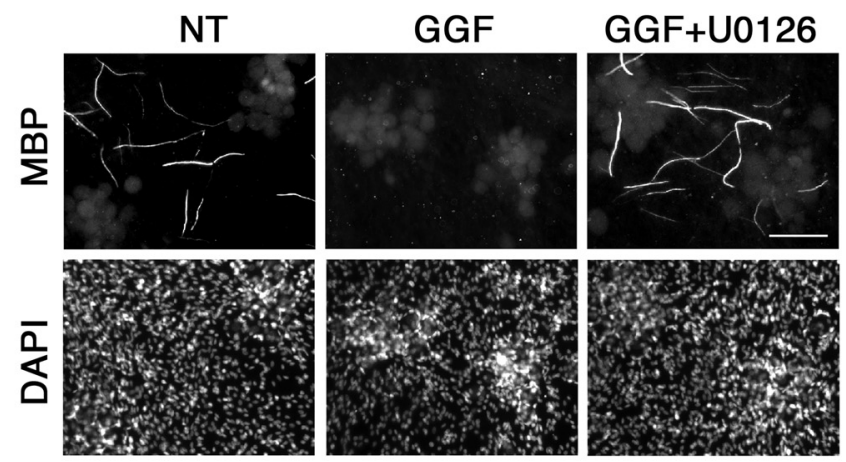

C

D
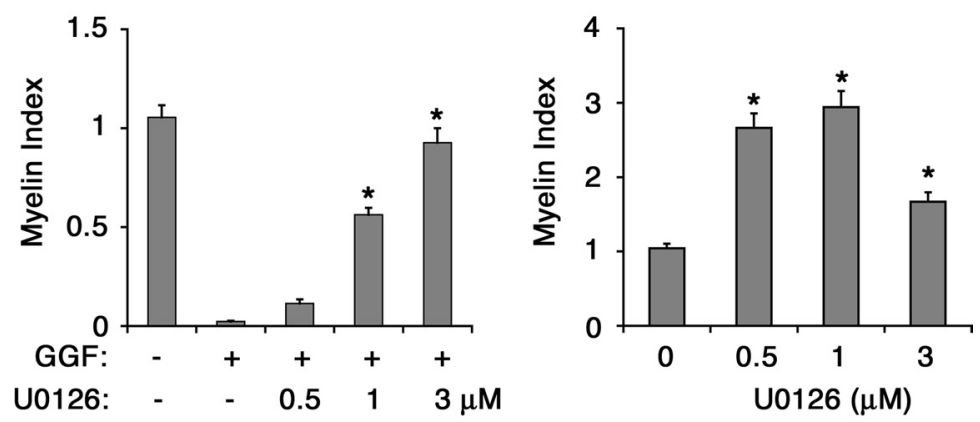

E

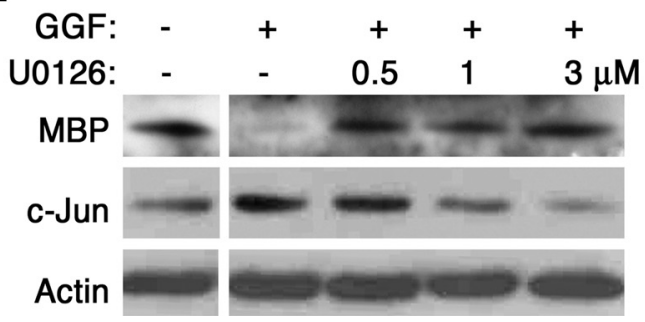

Figure 5. Inhibitory effect of GGF on myelination is blocked by inhibition of the Mek/Erk activation. A, Inhibition of GGF-induced Erk activation in cocultures. Schwann cell-DRG cocultures were pretreated with U0126 for $30 \mathrm{~min}$ at indicated doses followed by GGF treatment $(0.6 \mathrm{~nm})$. Forty-five minutes later, cell lysates were prepared and the levels of $p$-Erk and p-Akt were determined. Treatment with U0126 inhibited both endogenous and GGF-induced Erk activation without affecting Akt activation. B, Images of $\mathrm{MBP}^{+}$myelin segments in 11 day myelinating cocultures maintained with GGF alone or in combination with U0126 (1 nM). NT, Nontreated. C, Quantification of myelination in cultures treated with GGF and increasing doses of U0126 $(0.5,1$, and $3 \mu \mathrm{M})$. Treatment with U0126 abolished the inhibitory effect of GGF and increased myelination $\left({ }^{*} p<0.001\right)$. The means $( \pm$ SEM) were determined from 10 coverslips per condition from 2 independent experiments. $D$, In the absence of GGF, cocultures were treated with increasing concentration of U0126 under myelinating conditions, and myelination was analyzed as described above. A significant increase in myelination was observed in cultures treated with U0126 $\left({ }^{*} p<0.001\right)$. $\boldsymbol{E}$, Inhibition of GGF-induced Mek/Erk activation is accompanied by a decrease in c-Jun and an increase in MBP expression. Cocultures were maintained under myelinating conditions in the presence of GGF alone or in combination with $\mathrm{U} 0126(0.5,1$, and $3 \mathrm{nM})$ for $11 \mathrm{~d}$, and the cell lysates were analyzed for MBP and c-Jun expression. Levels of actin are shown as loading control.

tion (Fig. 1). Since we did not observe any noticeable differences in either erbB2 or erbB3 activation kinetics in Schwann cells treated with the neuregulins (Fig. 4A), we hypothesized that the isoform-specific effects on myelination might be due to differ- ential activation of the receptor downstream signaling pathways. Previous studies have implicated the Ras/Raf/Erk and PI3 kinase pathways as negative and positive regulators of myelination, respectively, and suggested that the balance between the two may determine the myelination state of the Schwann cells (Maurel and Salzer, 2000; Harrisingh et al., 2004; Ogata et al., 2004). Therefore, we compared the activation states of the two pathways in cocultures treated with increasing concentrations of EGF-Nrg1, GGF, or soluble Nrg1 type III. Cell lysates were prepared 45 min following the Nrg1 treatment under myelinating conditions, and the presence of the phosphorylated proteins was determined by Western blot analysis (Fig. 4B). Activation of erbB2 and Akt appeared at concentrations as low as $0.1 \mathrm{~nm}$ with all three Nrg1 isoforms and increased thereafter in a dose-dependent manner. While 0.3 and $0.6 \mathrm{~nm}$ EGF-Nrg1 and GGF, respectively, were sufficient to activate Erk, a much higher dose (10 nM) was needed for sNrgl type III to induce Erk activation. At $1 \mathrm{~nm}$ (Fig. $4 B$, boxed lanes), one of the concentrations tested for myelination in Figure 1, the inhibitory Nrg1 isoforms (GGF and EGF-Nrg1) activated both Akt and Erk, whereas Nrg1 type III predominantly activated Akt.

To determine whether the Erk activation was associated with the inhibitory effect of GGF, cocultures were treated with GGF along with increasing concentrations of U0126, a specific inhibitor of Erk activator Mek1/2, and maintained under myelinating conditions. Western blot analysis presented in Figure $5 A$ shows that U0126 successfully inhibited GGFinduced Erk activation in a dosagedependent manner while it had no effect on Akt activation ( + GGF lanes). Next, we assessed the effect of Mek1/2 inhibition on myelination (Fig. $5 B, C$ ). Addition of U0126 to cocultures reversed the inhibitory effect of GGF, indicated by the dosedependent increase in myelination. This result suggests that Mek1/2 and possibly the downstream effector Erk is likely to mediate the inhibitory effect of GGF on myelination. This result is in agreement with the previous report that growth factor-induced Mek activity inhibits myelin gene expression in Schwann cells (Ogata et al., 2004). It is also interesting to note that a continuous treatment with U0126 alone, in the absence of GGF, was sufficient to increase myelination (Fig. 5D). This result suggests that the endogenous Mek/Erk activity in cocultures is likely to work in parallel with GGF to provide an additional negative signal for myelination. 

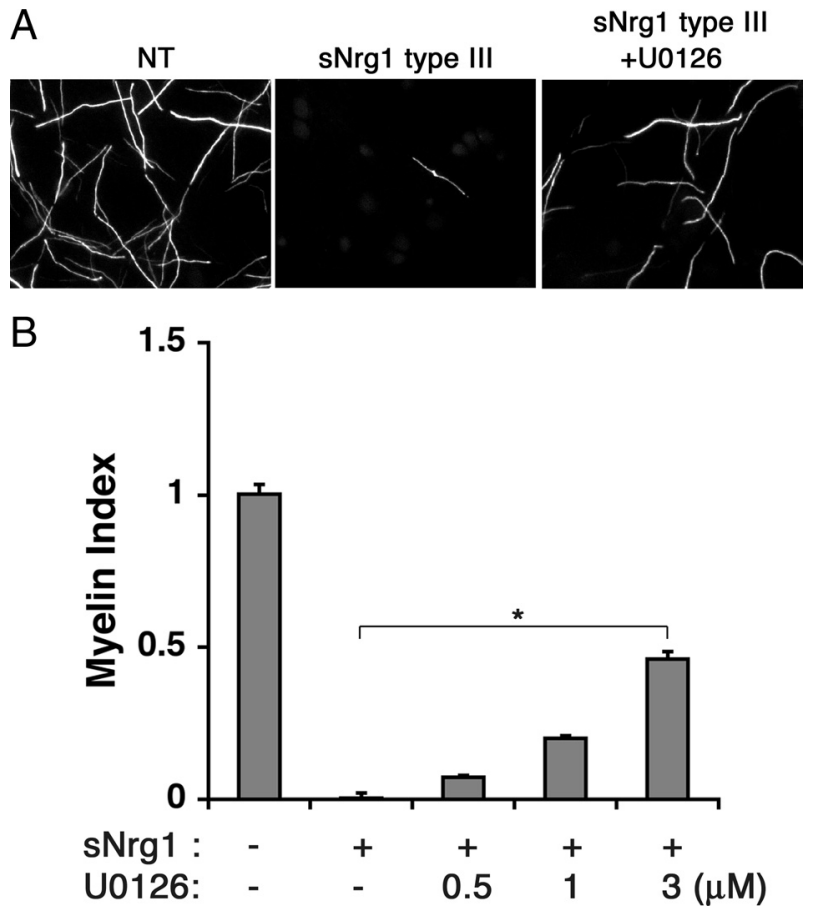

Figure 6. Soluble Nrg1 type III inhibits myelination at high concentrations in a manner that is dependent on Mek/Erk activation. $\boldsymbol{A}, \boldsymbol{B}$, Cocultures were maintained in myelinating media in the presence of $10 \mathrm{~nm}$ soluble $\mathrm{Nrg} 1$ type Ill in the absence or presence of $\mathrm{U} 0126(0.5,1$, and $3 \mathrm{~nm})$. Eleven days later, myelination was evaluated. Images of the cultures are shown in $\boldsymbol{A}$, and quantification of the result is shown in $\boldsymbol{B}$. Soluble Nrg1 type III almost completely inhibited myelination. Cotreatment with 00126 reversed the inhibitory effect in a dose-dependent manner $\left({ }^{*} p<0.001\right)$. NT, Nontreated.

To determine a possible mechanism by which GGF blocks myelination, we investigated the expression levels of c-Jun, a transcription factor recently described as an inhibitor of Schwann cell differentiation and myelination (Parkinson et al., 2008). Western blot analysis on lysates prepared from cocultures revealed that GGF treatment increased expression of c-Jun protein (Fig. 5E). Subsequent treatment with U0126 decreased the c-Jun level in a dose-dependent manner, indicating that the GGFinduced c-Jun expression was dependent on Mek/Erk activity. The decrease in c-Jun was also accompanied by an increase in myelin basic protein expression. These results suggest that the inhibitory effect of GGF on myelination is associated with its induction of c-Jun through the activation of the Mek/Erk pathway.

\section{Soluble Nrg1 type III inhibits myelination at high concentrations in a Mek/Erk-dependent manner} We observed that soluble Nrg1 type III began to activate Erk in the cocultures when used at high concentrations (10 nM) (Fig. $4 B$ ), suggesting a possibility that it might elicit a negative effect on myelination when the concentration was increased. A series of myelination assays showed that myelination was indeed inhibited in cultures treated with a high-concentration, soluble Nrg1 type III (Fig. 6A,B), which was in contrast to the promyelinating function at lower doses demonstrated in Figures 1-3. As with GGF, the inhibitory effect was dependent on Mek/Erk activation, as cotreatment with U0126 blocked the inhibitory effect and increased myelination. These results suggest that the promyelinating function of soluble Nrgl type III might not be isoform specific, but rather concentration dependent.

\section{GGF promotes Schwann cell myelination at} low concentrations

Next, we investigated whether GGF, previously regarded as the Nrg1 isoform that inhibits myelination, would elicit a similar concentration-dependent dual effects as seen with soluble Nrg1 type III. To address this, we first assessed the concentrationdependent Akt and Erk activation kinetics in cocultures treated with low concentrations of GGF, ranging from 0.0005 to $1 \mathrm{nM}$. As shown in Figure $7 A$, Akt activation increased at doses as low as $0.0005 \mathrm{~nm}$, whereas a noticeable increase in Erk activity did not appear until $0.3 \mathrm{~nm} \mathrm{GGF}$ was used. Consequently, the differential activation of Akt and Erk at the low concentrations generated a narrow range of doses, i.e., between 0.0005 and $0.01 \mathrm{nM}$, in which Akt was the predominant pathway activated in response to GGF (Fig. 7A, bottom, boxed concentration window). Myelination assay cocultures showed that within the low concentration range, GGF elicited a promyelinating effect in a dose-dependent manner: 1.5-, 2.3-, 2.2-, and 2.8-fold increase in myelination at $0.0005,0.001,0.003$, and $0.01 \mathrm{nM}$ GGF, respectively, compared with the control (Fig. 7B). At higher concentrations GGF inhibited myelination, coinciding with the appearance of Erk activation as shown in Figure 1. Low doses of GGF were also able to increase myelination on Nrg1 type $\mathrm{III}^{+/-}$neurons (Fig. 7C), indicating a direct promyelinating effect similar to that of soluble Nrg1 type III. Altogether, these results show that ectopic stimulation with soluble Nrg1 can both promote and inhibit myelination, and the isoform-independent binary choice is determined by a dose-dependent differential activation of the downstream signaling pathways in Schwann cells.

\section{Discussion}

Ectopic stimulation with soluble Nrg1 promotes myelination Myelination is a complex cellular process that proceeds in several distinct stages. Before initiating myelination, Schwann cells align themselves along the axons and begin the process of radial sorting, adopting a 1:1 relationship with the axons to be myelinated. Concomitantly, Schwann cells become polarized by positioning themselves between the axon and the basal laminae, establishing two distinct membrane domains. This is followed by continuous extension and migration of the inner Schwann cell membrane around the circumference of the axon and, lastly, compaction of the membrane by exclusion of the cytoplasm to the cell periphery.

The membrane-bound Nrgl type III is a key axonal protein required for myelination in the PNS; however the molecular mechanisms by which it regulates and promotes myelination remain unclear. A recent study has suggested two distinct roles of the axonal Nrg1 during myelination (Taveggia et al., 2005). In neurons lacking Nrg1 type III expression (Nrg1 type III ${ }^{-/}$), Schwann cells do not ensheath or segregate the axons properly and, as a result, fail to myelinate, indicating that the Nrg1 function is essential during the premyelination process. The study has also shown that expression of promyelinating transcription factors in Schwann cells is sensitive to the amount of Nrg1 type III expressed on the associated axons, thus suggesting a direct role of Nrg1 in myelination. By demonstrating that the myelination defect on Nrgl type III ${ }^{-/-}$neurons could not be rescued by ectopic stimulation with soluble Nrg1, the study further emphasized the importance of the "axonal" Nrg1 in initiating myelination.

Therefore, an intriguing finding of the present study is the rescue of the myelination defect in Nrg1 type $\mathrm{III}^{+/-}$cultures by soluble Nrg1 (Figs. 1, 2). Unlike Nrg1 type III ${ }^{-/-}$neurons, large axons of Nrg1 type III ${ }^{+/-}$neurons are ensheathed and sorted normally by the Schwann cells but poorly myelinated (Michailov 
A
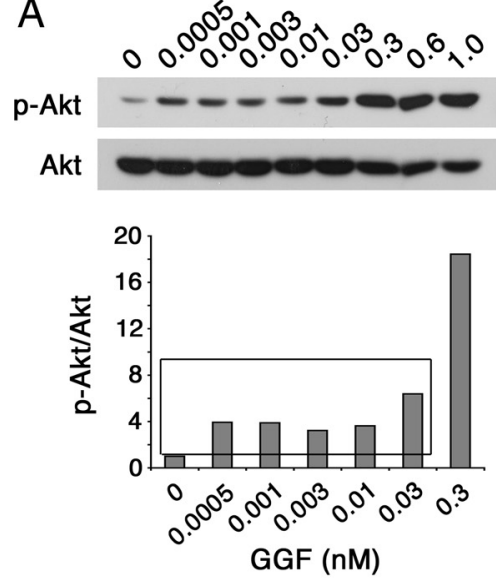

B
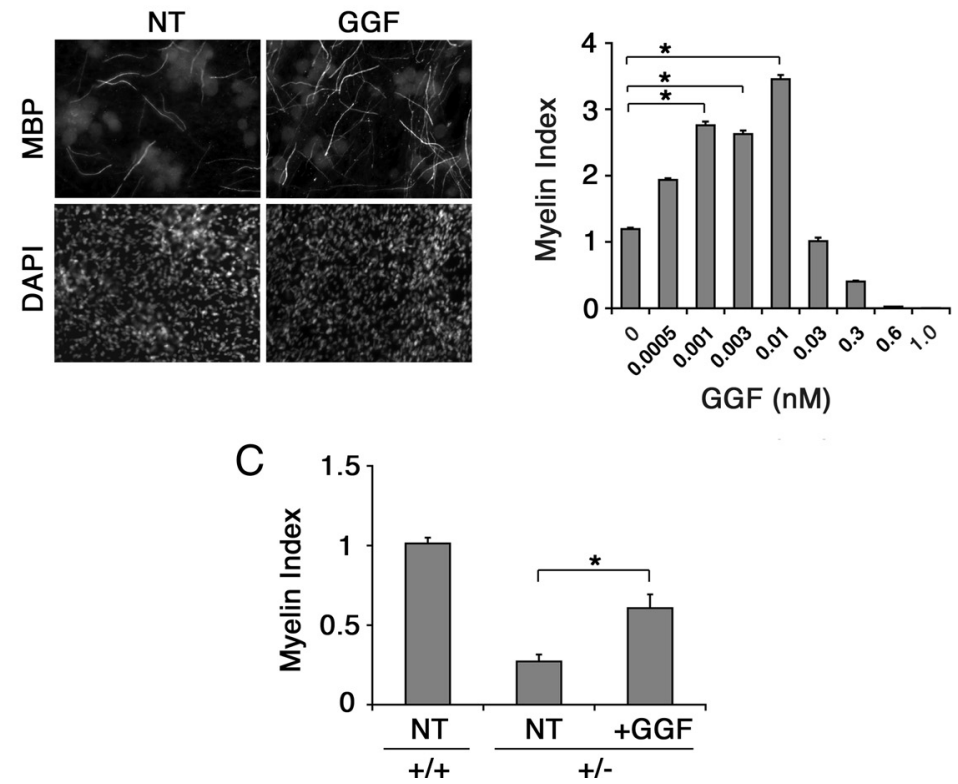

Figure 7. GGF promotes myelination at low concentrations. $\boldsymbol{A}$, Schwann cell-DRG cocultures were treated with increasing concentrations of GGF, ranging from 0.0005 to $1 \mathrm{~nm}$. Forty-five minutes later the cell lysates were prepared and the levels of Erk and Akt activation were determined by immunoblotting. Quantifications of the blots are shown at the bottom. A window of concentrations that shows predominant Akt activation is shown (boxed). $\boldsymbol{B}$, Cocultures were treated with different concentrations of GGF $(0.0005,0.001,0.003,0.01,0.03,0.3,0.6$, and $1 \mathrm{~nm})$ for $11 \mathrm{~d}$ under myelinating conditions and then fixed and immunostained for MBP and DAPI. Images of the control and cultures treated with $0.01 \mathrm{~nm} \mathrm{GGF}$ are shown along with the quantification of the result on the right. A significant increase in myelination was seen in cultures treated with GGF at concentrations between 0.0005 and 0.01 nm compared with the control ( $\left.{ }^{*} p<0.001\right)$. At $0.3 \mathrm{~nm}$ and higher, GGF inhibited myelination. The means from 12 coverslips/ condition from four separate experiments are shown. C, Low concentration of GGF ( $0.01 \mathrm{~nm})$ significantly increased myelination on Nrg1 type $I I{ }^{+/-}$neurons $\left({ }^{*} p<0.001\right)$. Error bars show \pm SEM. NT, Nontreated.

et al., 2004; Taveggia et al., 2005). Addition of soluble Nrg1, as shown in this study, then increases expression levels of Krox 20 and myelin proteins, leading to enhanced myelination. These data suggest that soluble Nrg1 elicits a promyelinating function, independent of the previous sorting process, that is likely to require membrane-bound axonal Nrgl type III. This notion is further supported by the finding that soluble Nrg1 also promotes myelination on axons of normally nonmyelinated SCG neurons (Fig. 3) that express low levels of Nrg1 type III (Taveggia et al., 2005) but are properly ensheathed and segregated by the associated Schwann cells.

\section{Axonal Nrg1 type III is required for the early events} of myelination

The rescue of myelination by soluble Nrg1 of Nrg1 type $\mathrm{III}^{+/-}$ but not Nrg1 type III ${ }^{-/-}$neurons implies the exclusive require- ment of juxtacrine Nrg1 signaling during early events of axonal segregation and ensheathment. The mechanism by which membrane-bound Nrg1 regulates early axon-Schwann cell interaction remains unknown. It is possible that activation of Nrg1-erbB receptor signaling at the Schwann cell-axon interface is important for establishing the initial polarity before myelination. In polarized epithelial cells, domain-specific activation of erbB2 regulates differentiation phenotype (Ramsauer et al., 2006). It is also possible that Nrg1-erbB cooperates with other cell surface receptors or adhesion molecules that function at the axon-glial interface. Neurotrophin receptor p75 is required for myelination and is localized to the adaxonal domain through its interaction with polarity protein Par-3 (Chan et al., 2006). Several cell adhesion molecules, including cadherins and nectin-like proteins, have also been shown to mediate axon-Schwann cell interaction at this junction and are required for myelination (Wanner et al., 2006; Maurel et al., 2007; Spiegel et al., 2007). Whether the erbB receptor complex interacts with these proteins at the junction or whether the interaction has a functional significance during early events of myelination remains unknown. It is also possible that the spatial opposition between the Nrg1-erbB and the basal lamina-integrin signal at the abaxonal junction is required for the premyelination process (Benninger et al., 2007; Nodari et al., 2007).

\section{Soluble Nrg1 can both promote and inhibit myelination: a binary choice determined by the concentration}

In the PNS, GGF has been regarded as the Nrg1 isoform associated with the Schwann cell injury response that inhibits myelination (Huijbregts et al., 2003). Thus, an unexpected result of this study was the myelination-promoting effect of GGF when used at low concentrations. A similar observation was made with sNrg1 type III, which at high concentrations inhibited myelination, while at low doses promoted the process. This is an intriguing finding, as it demonstrates that independently of the isoforms, soluble Nrg1 can elicit two contrasting biological functions under the same cellular context based solely on the amount presented to the cell. This can be explained by a concentrationdependent differential activation of the receptor downstream signaling effectors in Schwann cells shown by all three Nrg1 isoforms; our data show that the promyelinating function of Nrg1 is observed at concentrations that preferentially activate Akt, while the transition into the inhibitory role at higher concentrations coincides with the appearance of Erk activation. Consequently, inhibition of the Nrg1-induced Erk activity reverses the inhibitory effect on myelination. These results support the previous notion that the overall balance between PI3-kinase and 
Ras/Raf/Erk activation determines the myelination state of Schwann cells (Ogata et al., 2004). Alternatively, it is also possible that Nrg1 might have an indirect effect on the signaling events that occur in neurons through the associated Schwann cells, thus regulating myelination (Esper and Loeb, 2004).

In the CNS, while Nrg1 type III function is not required for initiating myelination, its ectopic expression in CNS neurons nevertheless enhances myelination (Brinkmann et al., 2008). Soluble Nrg1 also promotes myelination in oligodendrocyte progenitor cell-DRG cocultures; however, it does not exhibit an inhibitory effect on oligodendrocyte myelination (Wang et al., 2007). This suggests differences in the mechanisms by which myelination is regulated in oligodendrocytes and Schwann cells.

\section{The inhibitory function of Nrgl on myelination is likely to be mediated through activation of the Mek/Erk pathway}

The Ras/Raf/Erk pathway plays an inhibitory role during Schwann cell differentiation by blocking myelin gene expression (Harrisingh et al., 2004; Ogata et al., 2004). However, its direct role during myelination has not been elucidated. Here, we show that treatment with Mek1/2 inhibitor blocks the inhibitory role of ectopic soluble Nrg1 and restores myelination, suggesting that the inhibitory role of $\mathrm{Nrg} 1$ is likely to be mediated through its activation of the Mek/Erk pathway. The mechanism by which Mek/Erk activation inhibits myelination is unclear. A possible mechanism includes suppression of myelin gene expression as described above. Supporting this, our data show that Mek1/2 inhibition increases MBP expression in GGF-treated cultures (Fig. 4). It is also possible that the Mek/Erk pathway regulates the expression of transcription factors involved in Schwann cell differentiation and myelination. Recently, it has been shown that c-Jun functions as a negative regulator of the myelination program in the PNS (Parkinson et al., 2008). Accordingly, we find that the inhibitory effect of GGF is accompanied by an increase in c-Jun expression, which is suppressed when Mek is inhibited. This, therefore, suggests that the Mek/Erk function on myelination is in part mediated through induction of c-Jun.

Another interesting finding of the present study is the presence of an intrinsic Mek/Erk-dependent signal that serves as a negative regulator of myelination. This was shown in experiments in which treatment of normal myelinating cocultures with the Mek inhibitor promoted myelination. The nature of the signal that contributes to the Mek/Erk activity during myelination is presently unknown, although it is likely to be axonal in origin, independent of the axonal Nrg1 type III (Taveggia et al., 2005). Several Mek/Erk activators, such as FGF-2 and PDGF, are expressed on PNS neurons and their receptors are found on Schwann cells (Hardy et al., 1992; Eccleston et al., 1993; Oellig et al., 1995; Grothe and Wewetzer, 1996). Treatment with FGF-2 downregulates myelin gene expression and inhibits myelination in vitro (Zanazzi et al., 2001). It will be of great interest to assess the regulatory roles of these growth factors during myelination in the PNS.

\section{Therapeutic potential of soluble Nrg1}

The rebuilding of myelin in demyelinated lesions in the nervous system by transplanting exogenous myelin-forming glial cells is a concept that has been explored and tested for many years. Schwann cells offer the possibility of autologous transplantation, as they are easily obtained and expanded in culture and myelinate when transplanted in demyelinated lesions (Duncan et al., 1981; Baron-Van Evercooren et al., 1992; Morrissey et al., 1995). However Schwann cell remyelination of adult axons is often incom- plete, resulting in the formation of thinner myelin sheathes and shorter internodes compared with normal nerves (Beuche and Friede, 1985; Kohama et al., 2001; Lankford et al., 2002). The promyelinating effect of soluble Nrg1 presented in this study is significant, as it provides a potential therapeutic strategy for improving myelination by Schwann cells. However, it should be cautioned that concentrations above the threshold level could have a devastating consequence on the pathologic condition. Further understanding of the inhibitory role of Ras/Raf/Erk pathway on myelination might provide insights into developing a combined strategy for improving myelination.

\section{References}

Baron-Van Evercooren A, Gansmuller A, Duane E, Pascal F, Gumpel M (1992) Repair of a myelin lesion by Schwann cells transplanted in the adult mouse spinal cord. J Neuroimmunol 40:235-242.

Benninger Y, Thurnherr T, Pereira JA, Krause S, Wu X, Chrostek-Grashoff A, Herzog D, Nave KA, Franklin RJ, Meijer D, Brakebusch C, Suter U, Relvas JB (2007) Essential and distinct roles for cdc42 and racl in the regulation of Schwann cell biology during peripheral nervous system development. J Cell Biol 177:1051-1061.

Beuche W, Friede RL (1985) A new approach toward analyzing peripheral nerve fiber populations. II. Foreshortening of regenerated internodes corresponds to reduced sheath thickness. J Neuropathol Exp Neurol 44:73-84.

Brinkmann BG, Agarwal A, Sereda MW, Garratt AN, Muller T, Wende H, Stassart RM, Nawaz S, Humml C, Velanac V, Radyushkin K, Goebbels S, Fischer TM, Franklin RJ, Lai C, Ehrenreich H, Birchmeier C, Schwab MH, Nave KA (2008) Neuregulin-1/ErbB signaling serves distinct functions in myelination of the peripheral and central nervous system. Neuron 59:581-595.

Brockes JP, Fields KL, Raff MC (1979) Studies on cultured rat Schwann cells. I. Establishment of purified populations from cultures of peripheral nerve. Brain Res 165:105-118.

Chan JR, Jolicoeur C, Yamauchi J, Elliott J, Fawcett JP, Ng BK, Cayouette M (2006) The polarity protein Par-3 directly interacts with p75NTR to regulate myelination. Science 314:832-836.

Duncan ID, Aguayo AJ, Bunge RP, Wood PM (1981) Transplantation of rat Schwann cells grown in tissue culture into the mouse spinal cord. J Neurol Sci 49:241-252.

Eccleston PA, Funa K, Heldin C-H (1993) Expression of platelet-derived growth factor (PDGF) and PDGF alpha- and beta-receptors in the peripheral nervous system: an analysis of sciatic nerve and dorsal root ganglia. Dev Biol 155:459-470.

Eldridge CF, Bunge MB, Bunge RP, Wood PM (1987) Differentiation of axon-related Schwann cells in vitro. I. Ascorbic acid regulates basal lamina assembly and myelin formation. J Cell Biol 105:1023-1034.

Esper RM, Loeb JA (2004) Rapid axoglial signaling mediated by neuregulin and neurotrophic factors. J Neurosci 24:6218-6227.

Falls DL (2003) Neuregulins: functions, forms, and signaling strategies. Exp Cell Res 284:14-30.

Grothe C, Wewetzer K (1996) Fibroblast growth factor and its implications for developing and regenerating neurons. Int J Dev Biol 40:403-410.

Hardy M, Reddy UR, Pleasure D (1992) Platelet-derived growth factor and regulation of Schwann cell proliferation in vivo. J Neurosci Res 31:254-262.

Harrisingh MC, Perez-Nadales E, Parkinson DB, Malcolm DS, Mudge AW, Lloyd AC (2004) The Ras/Raf/ERK signalling pathway drives Schwann cell dedifferentiation. EMBO J 23:3061-3071.

Ho WH, Armanini MP, Nuijens A, Phillips HS, Osheroff PL (1995) Sensory and motor neuron-derived factor: a novel heregulin variant highly expressed in sensory and motor neurons. J Biol Chem [Erratum (1995) 270:26722] 270:14523-14532.

Holmes WE, Sliwkowski MX, Akita RW, Henzel WJ, Lee J, Park JW, Yansura D, Abadi N, Raab H, Lewis GD, Shepard HM, Kuang WJ, Wood WI, Goeddel DV, Vandlen RL (1992) Identification of heregulin, a specific activator of p185erbB2. Science 256:1205-1210.

Huijbregts RP, Roth KA, Schmidt RE, Carroll SL (2003) Hypertrophic neuropathies and malignant peripheral nerve sheath tumors in transgenic mice overexpressing glial growth factor $\beta 3$ in myelinating Schwann cells. J Neurosci 23:7269-7280.

Johnson MI (2001) Primary cultures of sympathetic ganglia. In: Protocols 
for neural cell culture, Ed 3 (Fedoroff S, Richardson A, eds), pp 71-94. Totowa, NJ: Humana.

Kohama I, Lankford KL, Preiningerova J, White FA, Vollmer TL, Kocsis JD (2001) Transplantation of cryopreserved adult human Schwann cells enhances axonal conduction in demyelinated spinal cord. J Neurosci 21:944-950.

Lankford KL, Imaizumi T, Honmou O, Kocsis JD (2002) A quantitative morphometric analysis of rat spinal cord remyelination following transplantation of allogenic Schwann cells. J Comp Neurol 443:259-274.

Lu HS, Chang D, Philo JS, Zhang K, Narhi LO, Liu N, Zhang M, Sun J, Wen J, Yanagihara D, Karunagaran D, Yarden Y, Ratzkin B (1995) Studies on the structure and function of glycosylated and nonglycosylated neu differentiation factors: similarities and differences of the alpha and beta isoforms. J Biol Chem 270:4784-4791.

Marchionni MA, Goodearl AD, Chen MS, Bermingham-McDonogh O, Kirk C, Hendricks M, Danehy F, Misumi D, Sudhalter J, Kobayashi K, Wroblewski D, Lynch C, Baldassare M, Hiles I, Davis JB, Hsuan JJ, Totty NF, Otsu M, McBurney RN, Waterfield MD, Stroobant P, Gwynne D (1993) Glial growth factors are alternatively spliced erbB2 ligands expressed in the nervous system. Nature 362:312-318.

Maurel P, Salzer JL (2000) Axonal regulation of Schwann cell proliferation and survival and the initial events of myelination requires PI 3-kinase activity. J Neurosci 20:4635-4645.

Maurel P, Einheber S, Galinska J, Thaker P, Lam I, Rubin MB, Scherer SS, Murakami Y, Gutmann DH, Salzer JL (2007) Nectin-like proteins mediate axon Schwann cell interactions along the internode and are essential for myelination. J Cell Biol 178:861-874.

Michailov GV, Sereda MW, Brinkmann BG, Fischer TM, Haug B, Birchmeier C, Role L, Lai C, Schwab MH, Nave KA (2004) Axonal neuregulin-1 regulates myelin sheath thickness. Science 304:700-703.

Morrissey TK, Kleitman N, Bunge RP (1995) Human Schwann cells in vitro. II. Myelination of sensory axons following extensive purification and heregulin-induced expansion. J Neurobiol 28:190-201.

Nodari A, Zambroni D, Quattrini A, Court FA, D’Urso A, Recchia A, Tybulewicz
VL, Wrabetz L, Feltri ML (2007) Betal integrin activates Rac1 in Schwann cells to generate radial lamellae during axonal sorting and myelination. J Cell Biol 177:1063-1075.

Oellig C, Pirvola U, Taylor L, Elde R, Hokfelt T, Pettersson RF (1995) Acidic FGF and FGF receptors are specifically expressed in neurons of developing and adult rat dorsal root ganglia. Eur J Neurosci 7:863-874.

Ogata T, Iijima S, Hoshikawa S, Miura T, Yamamoto S, Oda H, Nakamura K, Tanaka S (2004) Opposing extracellular signal-regulated kinase and Akt pathways control Schwann cell myelination. J Neurosci 24:6724-6732.

Parkinson DB, Bhaskaran A, Arthur-Farraj P, Noon LA, Woodhoo A, Lloyd AC, Feltri ML, Wrabetz L, Behrens A, Mirsky R, Jessen KR (2008) c-Jun is a negative regulator of myelination. J Cell Biol 181:625-637.

Ramsauer VP, Pino V, Farooq A, Carothers Carraway CA, Salas PJ, Carraway KL (2006) Muc4-ErbB2 complex formation and signaling in polarized CACO-2 epithelial cells indicate that Muc4 acts as an unorthodox ligand for ErbB2. Mol Biol Cell 17:2931-2941.

Spiegel I, Adamsky K, Eshed Y, Milo R, Sabanay H, Sarig-Nadir O, Horresh I, Scherer SS, Rasband MN, Peles E (2007) A central role for Necl4 (SynCAM4) in Schwann cell-axon interaction and myelination. Nat Neurosci 10:861-869.

Taveggia C, Zanazzi G, Petrylak A, Yano H, Rosenbluth J, Einheber S, Xu X, Esper RM, Loeb JA, Shrager P, Chao MV, Falls DL, Role L, Salzer JL (2005) Neuregulin-1 type III determines the ensheathment fate of axons. Neuron 47:681-694.

Wang Z, Colognato H, Ffrench-Constant C (2007) Contrasting effects of mitogenic growth factors on myelination in neuron-oligodendrocyte cocultures. Glia 55:537-545.

Wanner IB, Guerra NK, Mahoney J, Kumar A, Wood PM, Mirsky R, Jessen KR (2006) Role of N-cadherin in Schwann cell precursors of growing nerves. Glia 54:439-459.

Zanazzi G, Einheber S, Westreich R, Hannocks MJ, Bedell-Hogan D, Marchionni MA, Salzer JL (2001) Glial growth factor/neuregulin inhibits Schwann cell myelination and induces demyelination. J Cell Biol 152: $1289-1299$. 